\title{
Vegetative propagation of raspberry from leafy cuttings
}

\author{
Priscila Monalisa Marchi ${ }^{1}$, Luis Eduardo Corrêa Antunes ${ }^{2}$, Ivan dos Santos Pereira ${ }^{3}$, \\ Daniela Höhn ${ }^{4}$, Ricardo Alexandre Valgas ${ }^{5}$
}

\begin{abstract}
The study aimed to evaluate rooting of raspberry cultivars from leafy cuttings in two seasons, autumn and winter. The cultivars Schöenmann, Willamette, Heritage, Polana, Indian Summer, Fall Gold, Golden Bliss and Bababerry were evaluated. Assessments were done 90 days after the installation for both seasons, evaluating the following traits: percentage of cuttings with callus; rooted and live cuttings; the longest root length; and dry mass of roots and sprouting. The results showed that is possible to obtain good rooting rates from leafy cuttings of raspberry cultivars in autumn, and regular in winter. The cultivars Bababerry, Schoenmann and Golden Bliss had higher rooting percentage, followed by Heritage, Polana, Willamette and Fallgold. The cultivar Indian Summer had the lower rooting percentage in autumn and winter.

Index terms: Rubus idaeus L., rooting, berries, seedlings production.

\section{Propagação vegetativa de brotações caulinares de framboeseira}

Corresponding author: priscilammarchi@yahoo.com.br

Received: November 27, 2017. Accepted: February 22, 2018.

Copyright: All the contents of this journal, except where otherwise noted, is licensed under a Creative Commons Attribution License.
Resumo-Este estudo teve como objetivo avaliar a propagação vegetativa de brotações caulinares de cultivares de framboeseira, no outono e no inverno. Foram avaliadas as cultivares Schöenmann, Willamette, Heritage, Polana, Indian Summer, Fall Gold, Golden Bliss e Bababerry. As avaliações, realizadas 90 dias após a instalação, em ambas estações, foram: porcentagem de estacas com calos, estacas enraizadas e sobreviventes; comprimento da maior raiz; massa seca de raízes e massa seca da parte aérea. É possível obter boas taxas de enraizamento de brotações caulinares de cultivares de framboeseiras no outono. As cultivares Bababerry, Schoenmann e Golden Bliss apresentaram maior percentual de enraizamento, seguidas por Heritage, Polana, Willamette e Fallgold. A cultivar Indian Summer teve o menor percentual e enraizamento no outono e no inverno.

Termos para indexação: Rubus idaeus L., enraizamento, pequenas frutas, produção de mudas.

\footnotetext{
${ }^{1}$ Agronomist, PhD Student in Agronomy, Plant Breeding, PPGA - UFPel. Pelotas-RS, Brazil. E-mail: priscilammarchi@yahoo.com.br ${ }^{2}$ Agronomist, Dr. in Agronomy, Researcher, Embrapa Temperate Agriculture.Pelotas-RS, Brazil. E-mail: luis.antunes@embrapa.br

${ }^{3}$ Agronomist, Dr. in Agronomy, Postdoc in Embrapa Temperate Agriculture.Pelotas-RS, Brazil. E-mal: ivanspereira@gmail.com

${ }^{4}$ Agronomist, PhD student in Agronomy - UFPel. Pelotas-RS, Brazil. E-mail: dani.hohn.sc@gmail.com

${ }^{5}$ Agronomist, MSc., Researcher, Embrapa Temperate Agriculture.Pelotas-RS, Brazil. E-mail: ricardo.valgas@embrapa.br
} 


\section{Introduction}

Raspberry (Rubus idaeus L.) is an economically important crop included in the small fruits group. This importance is due to the fruit's attractiveness as well as its appreciable amount of polyphenol and antioxidant activity, suggesting metabolic benefits for people's health (XIAO et al. 2017). Considering the production of temperate climate fruits in Brazil, small fruits are not yet very significant, except for strawberry. Raspberry, however, has gained great interest among growers and, consequently, has been expanding across temperate and subtropical Brazilian regions (CURI et al., 2015; CAPRONI et al., 2016).

The increasing demand for fruits and the expansion of raspberries requires obtaining plants with higher quality to implementing and renovating orchards (MARO et al., 2014). In this regard, the knowledge of propagation and seedlings production may be the first step to expand the species in Brazil (AFFONSO et al., 2015). Raspberry is notably almost exclusively propagated via cloning, an asexual method, in which individual plants produced are homogeneous and genetically identical to the mother plant (PACURAR et al., 2014). In this propagative method, for a plant segment to be able to live independently once detached from the mother plant, the regeneration and development of new roots is indispensable. The roots formed from post-embryonic organs are called adventitious roots (GUAN et al., 2015; PACURAR et al., 2014).

Therefore, the main ways to propagate this species is through rooting of softwood and hardwood cuttings, stem and root cuttings, beyond in vitro culture. The first one is not an efficient procedure, because from it, very low rooting rates are obtained (TIBERTI et al., 2015). Furthermore, stem rooting and root cuttings carry risks, such as soil pathogens contamination, low number of propagated plants and irregular plants. The in vitro tissues culture is the most efficient method to avoid contamination from pathogens (FAGUNDES et al., 2017), but the process is more expensive as it entails higher operational costs. The propagation of cuttings is considered the most efficient and cost-effective method to procedure large quantities of homogeneous plants (GUAN et al., 2015). In this way, the present research proposes to analyze rooting of leafy cuttings taken from axillary shoots from young cane, as an efficient and low cost method that also minimizes phytosanitary problems.

The aim of this research was to evaluate rooting of raspberry from leafy cuttings in two seasons.

\section{Material and methods}

The experiment was carried out in Pelotas-RS, Brazil. The latitude is $31^{\circ} 46^{\prime} \mathrm{S}$, longitude $52^{\circ} 20^{\prime} \mathrm{O}$, and altitude of 60 meters. The experimental design was completely randomized, arranged in an $8 \times 2$ factorial scheme with four replications of 12 leafy cuttings each, being eight raspberry cultivars, Schöenmann, Willamette, Heritage, Polana, Indian Summer, Fall Gold, Golden Bliss and Bababerry; and two seasons - autumn and winter. One-year-old plants used in this study were grown in a greenhouse, in $8 \mathrm{~L}$ plastic pots, filled with commercial peat substrate $\left(\right.$ Germinaplant $\left.{ }^{\circledR}\right)$ and $5 \mathrm{~g} \mathrm{~L}^{-1}$ of slow release fertilizer (Osmocote Plus ${ }^{\circledR}, 15-09-12$ ).

The first study was implement on March 11th, 2014 (autumn), and the second on June 20th, 2014 (winter), both 15 days after pruning and the removal of leaves. Leafy cuttings of $1-3 \mathrm{~cm}$ in length, each containing about 4-7 leaves, were taken from axillary shoots of the current year's new cane. They were vertically stablished at $1 \mathrm{~cm}$ depth, in expanded polystyrene trays with 120 cells, filled with vermiculite of fine particle size. The trays were maintained under intermittent misting for 6 seconds every 15 minutes.

Assessments were done 90 days after the installation of both experiments (autumn and winter). The cuttings were evaluated by the number of cuttings with callus appearing in relation to the total percentage of rooted cuttings, which were considered to be cuttings with at least one root; and the percentage of live cuttings, which were considered to be those with at least one pair of leaves.

The quality of rooted cuttings was evaluated by the parameters root length, which was measured by the average length of each of the cuttings' longest root. This measurement was taken with a graduated scale and were expressed in cm; dry mass of roots and sprouting, in which roots and sprouts from all cuttings were separated and dried, in a forced ventilation oven at $65^{\circ} \mathrm{C}$ until constant mass, followed by weighing in an analytical balance. The results were expressed in g cutting-1.

Results data were used to perform variance analysis. After finding significant variation for the studied traits among cultivars, means were compared using the Scott-Knott test $(\mathrm{p}<0.05)$. The measured traits were submitted to Pearson correlation, based on t-test at 5\% of probability.

\section{Results and discussion}

Differences were found $(\mathrm{p}<0.05)$ among cultivars regarding the percentage of live and rooted cuttings, in the longest root length and dry mass of sprouting for both climatic seasons (autumn and winter).

Percentage of cuttings with callus only differed in autumn (Table 1). In this season, more than $90.00 \%$ of the cuttings from cultivars Bababerry and Schöenmann produced callus, differing from all the others cultivars. However, 'Indian Summer' presented only $2.08 \%$ of cuttings with callus. These results are similar to those 
obtained by Campagnolo and Pio (2012) which evaluated propagation of stem and roots from ten blackberry cultivars, which belong to the same genus of Raspberries (Rubus). The authors found differences on the percentage of callus formation, ranging from $100 \%$ to $35 \%$. Based on these results, it was noticed that callus formation in raspberry leafy cuttings varies between cultivars. During the winter, very low callus percentages were observed $(0.00 \%$ to $14.58 \%)$.

Rooted cuttings in autumn ranged from $93.75 \%$ to $16.67 \%$, and from $50.00 \%$ to $8.33 \%$ in winter. During autumn, the cultivars Bababerry, Shoenmann and Golden Bliss presented highest root potential, followed by 'Heritage', 'Polana', 'Willamette' and 'Fallgold'. The cultivar Indian Summer presented a value of rooted cuttings lower than the other ones in autumn and winter, $16.67 \%$ and $8.33 \%$, respectively. These results are greater than those found in a study about raspberry root potential using stem cuttings, which showed only $3.12 \%$ as the maximum rate of rooted cuttings (TIBERTI et al., 2015). A hypothesis that may explain this discrepancy is that younger tissues, which contain stem cells, are more efficient at develop roots.

There are many factors that may explain this hypothesis, such as the distribution and the hormonal balance in the propagative material used, especially because auxin is the main hormone associated with rooting in plants (GUAN et al., 2015; PACURAR et al., 2014). This phytohormone is mainly synthesized in young leaves and meristems. In addition, the stem apex, which contains meristem, is a dynamic structure with high cellular activity, and the leaves make photosynthesis and produce metabolites. On the other hand, softwood stems present slower metabolic activity, reduced auxin rates, less cell differentiation and division, and lower levels of photo-assimilated compounds (TAIZ and ZEIGER, 2013). It is important to highlight that leaves probably favor raspberry rooting, because they are an important source of auxins, like 3-indol acetic acid (IAA) and an energy source. Vignolo et al. (2014) also observed that the presence of leaves provides more rooting of blackberry hardwood cuttings.

The presence of callus in cuttings propagated in autumn apparently favors the rooting process in raspberry cultivars. A high correlation between cuttings callus and rooted cuttings during this season $(\mathrm{r}=0.78, \mathrm{p}<0.001)$ was found. A study with Arabidopsis revealed that these calli are not a mass of unorganized cells; they have organized structures resembling the primordial of lateral roots (ATTA et al., 2009). Callus formation reproduces the initial development of lateral roots, but it does not continue after lateral root emergence. This is evidence that the process involved in pericycle cell division during the formation of lateral roots also occurs in callus formation. Thus, lateral roots and callus formation are under the same genetic control at the initiation step (SUGIMOTO et al., 2010).

The cultivars Bababerry, Schoenmann and Golden Bliss differ from the others because they have higher percentage of live cuttings in autumn, followed by 'Heritage', 'Polana', 'Willamette' an 'Fallgold'. In both seasons (autumn and winter), the cultivar Indian Summer differed from all others due to its lower percentage of live cuttings (Table 1). The Indian Summer cultivar is originated from the North East of the United States of America (USA), New York; while 'Bababerry', for example, which one had high percentage of live and rooted cuttings (Table 1), is originated from California, in West of USA. The results showed that climate conditions where the cultivars were created might influence in their adaptability to a different condition, even during propagation. The State of California has average of temperatures and rainfalls more similar to Southern of Brazil than the State of New York, where winter temperature average is below freezing. This influence is possibly related to the mother plant condition, its vigour and hormonal balance, which is dependent on adaptation, and certain amount of chilling hours might be necessary to develop roots. Although 'Indian Summer' plants are considered vigorous, mild winter conditions may not be favorable to plant adaptability and vegetative development of this cultivar.

The percentage of live cuttings was higher than the percentage of rooted cuttings for seven of all eight cultivars studied in autumn, and for six cultivars in winter. These results may indicate that some cultivars, in certain conditions, may need more time to develop roots. The presence of leaves in the cuttings does not influence on the percentage of live cuttings, but the reserves previously accumulated by them in the rooting process do (VIGNOLO et al., 2014).

For the longest root length trait, it was observed superiority for the cultivars Bababerry, Golden Bliss, Heritage and Willamette in autumn, and for the cultivars Bababerry, Schoenmann, Golden Bliss, Heritage, Polana, Willamette and Fallgold in winter (Table 1). Vignolo et al. (2014) reported differences for this trait in Blackberry cultivars. However, the dry mass of roots did not present differences in none of the seasons. According to Moubayidin et al. (2010), the root growth process is regulated by hormonal factors, where auxins are responsible for cell division, while cytokines act in cell differentiation. After root establishment, new hormonal controls take place, with requirement of lower concentrations of auxins for root meristem maintenance and cytokinins needed for root tissue differentiation (COSTA et al., 2013). It is clear that, in the conditions of this research, the cultivars had different auxin levels and similar cytokines levels.

Dry mass of sprouting was different in autumn and winter (Table 1). The cultivars Polana, Willamette and Indian Summer produced more dry mass of sprouting 
in autumn, and are superior from the other cultivars. In winter, 'Heritage' and 'Polana' stand out from the rest. Sprouts formation in cuttings works like a power drain, and if they predate rooting, it may lead to energy reserves exhaustion, prejudicing the rooting process or causing the death of cuttings.

The formation of adventitious roots is a complex genetic trait regulated by interactions between environmental and endogenous factors (PACURAR et al., 2014). This research shows that genetic factors have influence on raspberries root potential parameters. As it has been observed in other species of berries, like blackberry (CAMPAGNOLO and PIO, 2012; VIGNOLO et al., 2014) and Blueberry (MARANGON and BIASI, 2013). Nevertheless, other important factors play an important role in raspberries vegetative propagation, such as environmental and phytohormones variables (GUAN et al., 2015). In this respect, a large number of starch grains are present in cells that initiate root primordial; then, the mother plant condition is another determining factor, because these starch grains are associated with accumulation of carbohydrates and auxin at the basal part of the cuttings (GUAN et al., 2015). The events that lead to adventitious roots formation strongly depend on mother plant nutritional status, both in terms of mineral and carbohydrates, as well as on sink establishment at cuttings bases (COSTA et al., 2013).

The results presented in this paper may indicate that the propagation of raspberry leafy cuttings is a very promising alternative, but many factors influence in different ways the success of propagation. It was showed that better results are obtained in autumn, probably because environmental factors have influenced the vegetative propagation process, either through the nutritional condition of mother plant, or through climate conditions, that changes metabolic processes and rates in cuttings. Also, genetic factors play an important role due to the differences in vigour and hormonal balances of each raspberry cultivar. The technique is easy and has a low cost, and the type of propagating material is an important advantage, because the material used is very young, it means high hormonal rates, and besides there is no contact with soil, reducing significantly pathogens contamination risks.

Table 1 - Percentage of cuttings with calls, rooted and live cuttings, longest root length, dry mass of roots and dry mass of sprouting from leafy cuttings of raspberry cultivars in autumn and winter. Pelotas-RS, Brazil, 2017.

\begin{tabular}{|c|c|c|c|c|c|c|}
\hline Cultivar & $\begin{array}{c}\text { Cuttings } \\
\text { with calls } \\
(\%)\end{array}$ & $\begin{array}{c}\text { Rooted } \\
\text { cuttings } \\
(\%)\end{array}$ & $\begin{array}{c}\text { Live } \\
\text { cuttings } \\
(\%)\end{array}$ & $\begin{array}{c}\text { Longest root } \\
\text { length } \\
(\mathrm{cm})\end{array}$ & $\begin{array}{c}\text { Dry mass } \\
\text { of roots } \\
\left(\mathrm{g} \mathrm{cutting}^{-1}\right) \\
\end{array}$ & $\begin{array}{c}\text { Dry mass of sprouting } \\
{\left.\text { ( } \text { g cutting }^{-1}\right)}\end{array}$ \\
\hline \multicolumn{7}{|c|}{ 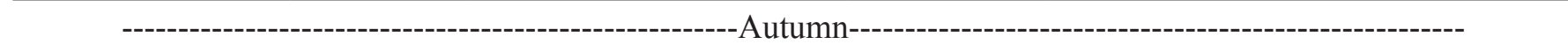 } \\
\hline Bababerry & $95.84 \mathrm{a}$ & $93.75 \mathrm{a}$ & $97.92 \mathrm{a}$ & $5.55 \mathrm{a}$ & $0.06 \mathrm{~ns}$ & $0.14 \mathrm{~b}$ \\
\hline Schoenmann & $93.75 \mathrm{a}$ & $79.17 \mathrm{a}$ & $93.75 \mathrm{a}$ & $4.37 \mathrm{~b}$ & 0.07 & $0.13 \mathrm{~b}$ \\
\hline Golden Bliss & $64.59 \mathrm{~b}$ & $81.25 \mathrm{a}$ & $81.25 \mathrm{a}$ & $5.75 \mathrm{a}$ & 0.07 & $0.17 \mathrm{~b}$ \\
\hline Heritage & $60.42 \mathrm{~b}$ & $56.25 \mathrm{~b}$ & $60.42 \mathrm{~b}$ & $5.35 \mathrm{a}$ & 0.09 & $0.16 \mathrm{~b}$ \\
\hline Polana & $56.25 \mathrm{~b}$ & $45.84 \mathrm{~b}$ & $58.33 \mathrm{~b}$ & $4.72 \mathrm{~b}$ & 0.23 & $0.21 \mathrm{a}$ \\
\hline Willamette & $52.09 \mathrm{~b}$ & $62.50 \mathrm{~b}$ & $70.84 \mathrm{~b}$ & $5.77 \mathrm{a}$ & 0.16 & $0.19 \mathrm{a}$ \\
\hline Fallgold & $43.75 \mathrm{~b}$ & $54.17 \mathrm{~b}$ & $70.83 \mathrm{~b}$ & $4.76 \mathrm{~b}$ & 0.11 & $0.16 \mathrm{~b}$ \\
\hline Indian Summer & $2.08 \mathrm{c}$ & $16.67 \mathrm{c}$ & $18.75 \mathrm{c}$ & $3.81 \mathrm{~b}$ & 0.16 & $0.25 \mathrm{a}$ \\
\hline Bababerry & $14.58 \mathrm{~ns}$ & $41.67 \mathrm{a}$ & $43.75 \mathrm{a}$ & $5.41 \mathrm{a}$ & $0.04 \mathrm{~ns}$ & $0.07 \mathrm{~b}$ \\
\hline Schoenmann & 2.08 & $49.67 \mathrm{a}$ & $50.00 \mathrm{a}$ & $5.14 \mathrm{a}$ & 0.06 & $0.12 \mathrm{~b}$ \\
\hline Golden Bliss & 0.00 & $30.00 \mathrm{a}$ & $40.00 \mathrm{a}$ & $4.91 \mathrm{a}$ & 0.18 & $0.03 \mathrm{~b}$ \\
\hline Heritage & 2.09 & $31.25 \mathrm{a}$ & $31.25 \mathrm{a}$ & $5.30 \mathrm{a}$ & 0.05 & $0.11 \mathrm{a}$ \\
\hline Polana & 2.00 & $33.33 \mathrm{a}$ & $35.42 \mathrm{a}$ & $5.21 \mathrm{a}$ & 0.04 & $0.11 \mathrm{a}$ \\
\hline Willamette & 6.25 & $50.00 \mathrm{a}$ & $54.17 \mathrm{a}$ & $5.49 \mathrm{a}$ & 0.04 & $0.06 \mathrm{~b}$ \\
\hline Fallgold & 6.20 & $43.75 \mathrm{a}$ & $48.85 \mathrm{a}$ & $4.63 \mathrm{a}$ & 0.06 & $0.04 \mathrm{~b}$ \\
\hline Indian Summer & 0.00 & $8.33 \mathrm{~b}$ & $26.67 \mathrm{~b}$ & $2.14 \mathrm{~b}$ & 0.04 & $0.06 \mathrm{~b}$ \\
\hline
\end{tabular}

*Lower case letters in the column differ significantly at the 5\% significance level by Scott-Knott test; ns means not significant at the $5 \%$ significance level by Scott-Knott test. 


\section{Conclusions}

It is possible to obtain good rooting rates from leafy cuttings of raspberry cultivars in autumn and regular in winter. In autumn, the cultivars Bababerry, Schoenmann and Golden Bliss have higher rooting percentage, followed by Heritage, Polana, Willamette and Fallgold. The cultivar Indian Summer have the lower rooting percentage in autumn and winter.

\section{References}

AFFONSO, L.B.; PEIL, R.M.N.; SCHUCH, M.W.; CAPPELLARO, T.H.; OZELAME, G.L.C. Microjardim clonal de mirtileiro em Sistema de cultivo sem solo. Revista Brasileira de Fruticultura, Jaboticabal, v.37, n.4, p.1037-1044, 2015.

ATTA, R.; LAURENS, L.; BOUCHERON-DUBUISSON, E.; GUIVARC'H, A.; CARNERO, E.; GIRAUDATPAUTOT, V.; RECH, P.; CHRIQUI, D. Pluripotency of Arabidopsis xylem pericycle underlies shoot regeneration from root and hypocotyl explants grown in vitro. Plant Journal, Barcelona, v.57, 626-644, 2009.

CAMPAGNOLO, M.A.; PIO, R. Enraizamento de estacas caulinares e radiculares de cultivares de amoreira-preta coletadas em diferentes épocas, armazenadas a frio e tratadas com AIB. Ciência Rural, Santa Maria, v.42, n.2, p. 232-237, 2012.

CAPRONI, C.M.; CURI, P.N.; MOURA, P.H.A.; PIO, R.; GONÇALVES, E.D.; PASQUAL, M. Blackberry and redberry production in crop and intercrop in Pouso Alegre, Southern Minas Gerais, Brazil. Ciência Rural, Santa Maria, v.46, n.10, p.1723-1728, 2016.

COSTA, C.T.; ALMEIDA, M.R.; RUEDELL, C.M.; SCHWAMBACH, J.; MARASCHIN, F.S.; FETT-NETO, A.G. When stress and development go hand in hand: main hormonal controls of adventitious rooting in cuttings. Frontiers in Plant Science, Hyderabad, v.14, n.4, p.133, 2013.

CURI, P.N.; PIO, R.; MOURA, P.H.M.; SOUSA, P.H.A.; BONFIM, G.D.; SILVA, P.A.O. Produtividade e qualidade da framboeseira 'Batum' cultivada sob cobertura plástica e dois espaçamentos em região subtropical. Ciência Rural, Santa Maria, v.45, n.11, p.1994-2000, 2015.

FAGUNDES, C.M.; MOREIRA, R.M.; RAMM, A.; SCHUCH, M.; TOMAZ, Z.F.P. Carvão ativado no estabelecimento in vitro de cultivares de framboeseira. Revista de Ciências Agroveterinárias, Lages, v.16, n.4, p.406-413, 2017.
GUAN, L.; MURPHY, A.S.; PEER, W.A.; GAN, L.; LI, Y.; CHENG, Z.M. Physiological and molecular regulation of adventitious root formation. Critical Reviews in Plant Sciences, London, v.34, n.5, p.506-521, 2015.

MARANGON, M.A.; BIASI, L.A. Estaquia de mirtilo nas estações do ano com ácido indolbutírico e aquecimento do substrato. Pesquisa Agropecuária Brasileira, Brasília, DF, v.48, n.1, p.25-32, 2013.

MARO, L.A.C.; PIO, R.GUEDES, M.N.S.; ABREU, C.M.P.; MOURA, P.H.A. Environmental and genetic variation in the post-harvest quality os raspberries in subtropical áreas in Brazil. Acta Scientiarum (Agronomy), Maringá, v.36, n.3, p. 323-328, 2014.

MOUBAYIDIN, L.; PERILLI, S.; DELLO LOIO, R.; DI MAMBRO, R.; CONSTANTINO, P.; SABATINI, S. The rate of cell differentiation controls the arabidopsis root meristem growth phase. Current Biology, New York, v.20, p.1138-1143, 2010.

PACURAR, D.I.; PERRONE, I.; BELLINI, C. Auxin is a central player in the hormone cross-talks that control adventitious rooting. Physiologia Plantarum, Copenhagen, v.151, p.83-96, 2014.

SUGIMOTO K.; JIAO, Y.; MEYERPWITZ, E.M. Arabidopsis regeneration from multiple tissues occurs via a root development pathway. Developmental Cell, Cambridge, v.18, p.463-471, 2010.

TAIZ, L.; ZEIGER, E. Fisiologia vegetal. 5.d. Porto Alegre: Artmed, 2013. 954p.

TIBERTI, A.S.; BIANCHINI, F.G.; PIO, R.; CURI, P.N.; MOURA, P.H.A.; TADEU, M.H. Armazenamento a frio e aplicação de reguladores vegetais no enraizamento de estacas radiculares e caulinares de framboeseira. Ciência Rural, Santa Maria, v.45, n.8, p.1445-1450, 2015.

VIGNOLO, G.K.; PICOLOTTO, L.; GONÇALVES, M.A.; PEREIRA, I.S.; ANTUNES, L.E.C. Presença de folhas no enraizamento de estacas de amoreira-preta. Ciência Rural, Santa Maria, v.44, n.3, p.467-472, 2014.

XIAO, D.; HUANG, Y.; PARK, E.; EDIRISINGHE, I.; BURTON-FREEMAN, B. Red raspberries and insulin action: understanding the role of red raspberry consumption on postprandial metabolic indices. FASEB Journal, Bethesda, v.31, n.1, p. 973-979, 2017. 